\title{
Avoiding isolation: Physical activity for persons with disabilities and Covid-19*
}

Authors' Contribution: A Study Design B Data Collection C Statistical Analysis D Data Interpretation E Manuscript Preparation F Literature Search G Funds Collection

\author{
Pelin Aksen-Cengizhan ${ }^{1}$ ABC, Ali Ahmet Doğan ${ }^{1}$ ABF, Özkan Işı| ${ }^{2}$ EF \\ ${ }^{1}$ Faculty of Sport Sciences, Kırıkkale University, Kırıkkale, Turkey \\ ${ }^{2}$ Faculty of Sport Sciences, Balıkesir University, Balıkesir, Turkey
}

\section{abstract}

Key words: persons with disabilities, physical activity, Covid-19, pandemic, social isolation.

\section{article details}

Article statistics: Word count: 3,702; Tables: 0; Figures: 0; References: 53

Received: December 2020; Accepted: March 2021; Published: September 2021

Full-text PDF: http://www.balticsportscience.com

Copyright @ Gdansk University of Physical Education and Sport, Poland

Indexation: Celdes, Clarivate Analytics Emerging Sources Citation Index (ESCI), CNKI Scholar (China National Knowledge Infrastructure), CNPIEC, DOAJ, EBSCO - Central \& Eastern European Academic Source, EBSCO - SPORTDiscus, EBSCO Discovery Service, Google Scholar, Index Copernicus, J-Gate, Naviga (Softweco, Primo Central (ExLibris), ProQuest - Family Health, ProQuest - Health \& Medical Complete, ProQuest - Illustrata: Health Sciences, ProQuest Nursing \& Allied Health Source, Summon (Serials Solutions/ProQuest, TDOne (TDNet), Ulrich's Periodicals Directory/ ulrichsweb, WorldCat (OCLC)

Funding: This research received no specific grant from any funding agency in the public, commercial, or not-for-profit sectors.

Conflict of interests: Corresponding author:

Open Access License: Authors have declared that no competing interest exists.

Pelin Aksen-Cengizhan, Kırıkkale Üniversitesi Spor Bilimleri Fakültesi Ankara Yolu 7.km 71450 Yahşihan/Kırıkkale/ TURKEY; phone: +905309320203; e-mail address: pelinaksen@gmail.com

This is an open access article distributed under the terms of the Creative Commons Attribution-Non-Commercial-NoDerivatives 4.0 International (https://creativecommons.org/licenses/by-nc-nd/4.0/), which permits use, distribution and reproduction in any medium, provided the original work is properly cited, the use is non-commercial and is otherwise in compliance with the license.

* This study was presented as an oral presentation at the Online International Conference of COVID-19 (CONCOVID) congress (12-14 June 2020). 


\section{INTRODUCTION}

In Wuhan, a major metropolitan city in China, a deadly new virus emerged in December 2019. On January 13, 2020, the genetic sequence of the virus was shared by the Chinese authorities [1]. On February 11, 2020, Dr. Tedros Adhanom Ghebreyesus, the Director General of the World Health Organization (WHO), announced that it was named as "Covid-19", an abbreviation of "Corona Virus Disease 2019" [2]. Covid-19 has a high infection rate and there is no effective treatment method, yet [3]. On March 11, 2020, the WHO declared Covid-19 as a rapidly spreading epidemic. The control of this rapidly spreading epidemic has now become a global public health issue [4, 5].

Virtually all countries in the world have been working to prevent possible destructive effects of Covid-19 and to take countermeasures. Health institutions have been coordinating the flow of information, and publishing methods and guidelines to minimize the impact of the threat. At the same time, scientists all around the world have been working to get answers to some important questions about the transmission of Covid-19 among humans, the clinical spectrum of the disease [4], infection symptoms, transmission of the virus in the sewage system, and methods of testing and diagnosis. There has been an increase in worldwide collaborative research to provide appropriate treatments for Covid-19 infected individuals, the creation of vaccines, and a better understanding of the origin of the virus [6]. Many uncertainties remain regarding both the virus-host interaction and the evolution of the pandemic [4].

\section{HEALTH EFFECTS OF INACTIVE LIFE DUE TO PANDEMIC IN DISABLED PEOPLE}

On March 26th, 2020, the WHO published a document which states that persons with disabilities are at higher risk and summarizes disability-related issues. This document also specifies measures to reduce the risk for persons with disabilities [7]. These measures include protective steps that outline the effects of social isolation under the Covid-19 restrictions on persons with disabilities. The document also contains recommendations for countries regarding the planning services for persons of disabilities and meeting their needs [8].

Today, outbreaks are spreading globally and much faster. According to the Turkey Disability Survey results published by the Turkish Statistical Institute in 2002, 12.3\% of the population have some form of disability: $2.6 \%$ experience orthopedic, visual, hearing, mental, speech and language impairments, and 9.7\% experience chronic illnesses [9]. The WHO's disability report has shown that more than 1 billion individuals of the world population (15\%) have a form of disability, and $2 \%-4 \%$ have difficulty in functioning [10].

The Covid-19 outbreak has affected everyone in the world in a way, especially those who are vulnerable and at risk, including persons with disabilities [11]. Similarly to emergencies caused by climate change and many disasters, during the Covid-19 outbreak, persons with disabilities may be four times more likely to be injured or die than those without disabilities [12]. The reason for this is not due to their vulnerable position, but due to the lack of consideration of their needs in urban health policies, planning, and implementation. The problem of urban health equity, which emerged after the Covid-19 outbreak and was adopted by the United Nations, has caused us to face the very common medical disability model that defines people as disabled due to their disability or differences. Ensuring urban health equity in cities means applying the social model of disability in all policies. For example, a street or a sidewalk that prevents a person in a wheelchair from crossing, or an intersection without proper lines is a limitation and failure of urban design, policy, and planning, not the disabled person. In addition, in low-income countries where $50-75 \%$ 
of the urban population live in slums or informal settlements, the challenges of social distancing for people with disabilities should not be viewed as an individual challenge, but rather as a failure [13].

Cities should ensure that people with disabilities continue to have access to essential services, including healthcare and personal assistants. During any closure or service limitations, persons with disabilities should be supported to meet their special dietary needs and their daily living needs, including access to food when needed, housing, health services, and home-schooling and community support [13]. The prohibition of discrimination against persons with disability, including reasonable regulations and changes to ensure equal access to effective health care, is well established in international law [14]. While the necessity of reasonable regulations and changes is not absolute, they aim to ensure that policies, practices, and procedures cover people with disabilities. Despite the improvements, research shows that many health facilities and medical equipment are inaccessible, and healthcare providers are often under-educated about the needs of the persons with disabilities. While these systematic shortcomings have led to worse health outcomes among the persons with disabilities, the unquestionable need for emergency response in the pandemic has further increased the challenges. However, it is essential to adopt measures that will facilitate the participation of the disabled patients in their care. For example, informed consent processes should be performed through direct interviews with patients and family members whenever possible. The already expanded use of telemedicine options to facilitate communication between clinicians, patients, caregivers and family members should include disability-friendly accessibility measures that can be downloaded to computers and mobile devices [15].

When we look at the effects of Covid-19 on the general population and the disabled, people with disabilities face inequalities in healthcare services compared to non-disabled people. For instance, autistic people find it difficult to access appropriate healthcare even in normal times. Providing accessible services for autistic individuals and other persons with disability is no longer a priority, as healthcare professionals have come to a breaking point. Professionals who find it difficult to choose which patients to give priority in providing care will find it less worth saving the lives of the persons with disability.

Compared to the general population, people with disabilities have less education, more economic, food, housing, and employment insecurity, and less internet access. The proportion of chronic medical conditions, such as obesity and cardiovascular disease, may be higher in people with mobility and mental disabilities, and adults with disabilities in general are three times more likely to have heart disease, stroke, diabetes, or cancer than non-disabled adults [15]. More importantly, research shows that individuals with mental or developmental disabilities are somewhat higher in risk of contracting Covid-19, possibly with higher morbidity, since the they may already have more problems with the immune and respiratory systems compared to the general population [16]. An important factor in reducing the spread of Covid-19 is social distancing. Social distancing may be impossible for people who live in group settings or need extensive support [17]. For this reason, it is suggested that family members and/or personal care providers should take extra precautions against high risk of infection in home to ensure the health and safety of the persons of disabilities, as they cannot fully implement social distancing [18]. Disabled homecare patients are recommended to have an independent area as they need isolation at home and to minimize the number of caregivers with them [19]. Informative health materials should inform people about possible changes and special recommendations. For example, if persons with mental disabilities cannot avoid touching their eyes, people who support them can help them wash their hands more often. Covering the mouth with the elbow while coughing may be impossible for persons with spinal cord injury 
or musculoskeletal conditions. Service providers should ensure that equipment used by physically disabled people, such as wheelchairs, handrails, and crutches, is frequently cleaned and disinfected, and that disabled people have access to water, and sanitation and hygiene facilities [15].

Individuals with Down syndrome are associated with other health conditions that increase the risk of becoming seriously ill due to Covid-19. If possible, they and those who support and provide care for them should be proactively tested for SARS-CoV-2 infection. Those who have been in contact with caregivers should also be recorded [20].

In cases where caregivers of persons with disabilities are in quarantine, a system should be developed in which a backup caregiver can meet the needs of the person with disability until the usual caregiver has fully recovered [3]. Public health strategies, especially applied to individuals with disabilities, should be followed within the framework of human rights during epidemic diseases [21].

The Covid-19 pandemic crisis poses a much more important challenge for persons with disabilities [5]. Restriction of mobility, loss of the routine, and reduced social and physical contact with others have caused distress, disappointment, and a sense of isolation [22]. On the other hand, regarding the autistic individuals, global panic, illness, and death in the media maximize anxiety in $40 \%$ of the autistic individuals [23-25]. About $10 \%$ of autistic individuals have physical disabilities along with autism [26] and have various chronic diseases [27]. This may increase susceptibility to Covid-19 [23]. While even under normal conditions autistic individuals may not receive proper health care $[14,28]$, it is thought that they will not be among the priorities in this pandemic process [23]. Autistic adults are much more likely to live in social isolation than people without disabilities [17]. On the other hand, since there is a negative relationship between social isolation and mental health [29], decreasing the support to individuals with mental disabilities may cause serious health problems. In addition to isolation due to social distancing during the pandemic, autistic individuals are likely to experience deterioration in their mental health by only being subjected to pandemic crisis [23]. Anxious and overwhelmed family members and anxious friends and caregivers negatively affect the safe and comfortable routines of the autistic individuals. Meeting the basic and social needs of the persons with disabilities requires a serious policy and follow-up process. For the persons with disabilities, improvements in several aspects, such as, medical rehabilitation services, supplying assistive technological devices, employment, education, eliminating personal and social barriers, transportation, communication, are very important [5].

Persons with mental disabilities and autistic adults may not have access to vital public health announcements. Government health announcements, often ambiguous and constantly changing, are rarely provided in an easy-to-read format for autistic individuals [23]. Public health messages for the persons with disabilities should be disseminated in plain language and in accessible formats through all mass communication channels. Public health messages and public announcements should be provided in sign language and in a simple, easy-to-read language, and in accessible environments and formats, including digital technology, subtitles, transfer services, and text messages $[13,24]$. Persons with visual impairment and those with low vision cannot access information conveyed by charts and graphs. If this information is not presented in plain language, it is also incomprehensible for persons with mental disability [15]. In addition, vital communication strategies, such as transparent masks, should be developed and accessible by sign language interpreters and healthcare providers to allow deaf and hearing-impaired individuals to read lips [30]. In order to facilitate communication with the deaf individuals, those having difficulty in hearing, or blind individuals, healthcare personnel should have a pen and paper or 
blackboard and markers in each hospital so that they can communicate with persons with such disabilities [15]. Transparent face masks provide lip reading advantages for those with severe hearing loss, especially in noisy hospital environments. Instructions for selfmade transparent masks are available on the social media; however, these masks have not been tested against general safety standards, so their level of protection may not be greater than a cloth mask [20].

Furthermore, persons with different types of disabilities should also be taken into consideration. For example, visually impaired individuals use the sense of touch in public places and amputees try to keep their prosthesis and limb hygiene. In Iran, which is one of the countries with a high mortality rate, educational materials were provided for these groups and their families/caregivers [5].

\section{THE EFFECT OF PANDEMIC ON MASS SPORTS}

While the Covid-19 pandemic has paralyzed transportation, businesses, logistics, and many other services, it has worsened the situation for people with disabilities who need timely medication or care, supplies and services, including assistive devices. As this crisis was surprising and unpredictable, sufficient supplies were not stored, and many people, including the disabled, were caught off guard. In addition, many service providers specifically targeting disabled people have been terminated [3]. Due to the Covid-19 epidemic, holidays and trade activities were canceled, shops were closed, services of logistics companies and many public institutions were either reduced or stopped [3], physical interaction was reduced through social distancing, sports events and concerts were cancelled, and restaurants and public places, including schools, were closed. On the other hand, the fact that children and parents had to be in the same apartment/house all day long instead of going to work or school routinely put a heavy burden on families [11]. While such efforts as staying at home to prevent the transmission of the virus to minimize the risk of local transmission of Covid-19 may be a safe method [31], restrictions have led to a reduction in physical activity [32]. Therefore, populations receiving therapeutic exercise programs as part of clinical management have also been significantly affected [22]. With the onset of the Covid-19 epidemic, there has been an increase in the number of online fitness channels developed to help individuals participate in exercises with a guide, thanks to safe, simple, and easy-to-follow exercise programs [6]. Equipment, application area, and difficulties of applications should be taken into consideration in $\square$ physical activities performed at home and some adaptations should be made.

While preparing exercise programs, it is necessary not only to adapt the movements to the home environment, but also to establish effective and purposeful communication. Thus, on the one hand, exercise satisfaction is increased, and on the other hand, a strong motivation can be attained [33]. It should also be noted that the attempted online service requires special training in this regard.

Novel systems in the world known as "telehealth" are necessary to ensure the maintenance of the exercises required to improve the functioning of the daily activities of the patients who normally receive care [34]. However, Telehealth options can cause difficulties for $\square$ people with psychiatric conditions, for fear of being tagged, if they would like to hide their condition and treatment from family members, or to conduct confidential interviews [15].

Ordinary video recordings provide individuals with an opportunity to watch the exercise programs repeatedly; however, they lack the advantages, such as motivation by an instructor, getting feedback on wrong actions, and individual guidance. There has been a dramatic increase in programs such as Zoom for exercises accompanied by an online 
guide, and instructors can provide live feedback from platforms like YouTube, which is normally a one-way online option. In addition, certain programs, such as the "Exercise Buddy" application, video models, visual supports, social narratives, technology-supported teaching and exercises have also been designed to support individuals with autism to be physically active. Although it is not free, it is thought that the exercises applied through such programs are quite good practices considering that they are advantageous in terms of motor control and safety [11].

\section{THE RELATIONSHIP BETWEEN PHYSICAL ACTIVITY AND THE IMMUNE SYSTEM IN THE PANDEMIC PROCESS}

Prevention is the strongest health promotion strategy. Therefore, it is essential to have a significantly stronger and more effective approach to global surveillance in the risks of major pandemic and epidemic infectious diseases [35].

Covid-19 is a new virus causing the respiratory disease epidemic [36] and affecting immune cells [37]. SARS-CoV-2 causes an infection in the alveolar epithelial cells via the ACE2 receptor. The destruction of epithelial cells and increased permeability causes the release of the virus, which triggers natural immunity. Natural immune cells, such as macrophages and neutrophils, both capture the virus and secrete numerous cytokines and chemokines. These cytokines and chemokines also allow monocytes and $\mathrm{T}$ lymphocytes to accumulate in the infected area. CD4+ helper T cells stimulate B cells to proliferate, differentiate, and produce virus-specific antibodies. CD8+T cells, on the other hand, limit the infection with their cytotoxic effects. If the infection cannot be cleared completely, it causes hyperinflammation. Hyperinflammation and cytokine storm syndrome are also observed in patients with severe Covid-19. Cytokine storm has been reported to cause secondary hemophagocytic lymphohistiocytosis and is associated with multiple organ failure and death [38]. Strong physical exercise leads to activation of the immune system, which includes cells capable of producing ROS, such as neutrophils, monocytes and macrophages [39, 40].

Physical activity causes an increase in immune cells and thereby strengthens the immune system [41]. Therefore, appropriate physical activities are suggested to increase the protective effects of the immune function against the virus before the onset of the disease $[42,43]$. The general consensus in the literature on exercise immunology is that the immune system responds positively to exercise, but this response depends on the severity, duration, and the type of the exercise $[41,44]$. Cardiovascular exercises make important contributions to the development of the immune system as they aim to strengthen the muscles attacked by the virus [45]. Epidemiological studies suggest that regular physical activity is associated with a decrease in the incidence and mortality of influenza and pneumonia [46]. In addition, Woods et al. [47] reported that regular exercises improved responses to vaccines [47].

Smith and Sparkes [48] maintain that physical activity can improve health and reduce the risk of chronic diseases for persons with disabilities [48]. They demonstrated a need for strength and balance exercises twice a week for a healthy life. It was also emphasized that adults with disabilities should exercise 150 minutes of moderate intensity for significant health gains. It was reported that $43 \%$ of the persons with disabilities in the UK were active for less than 30 minutes a week, while this rate was $21 \%$ for the persons with no disabilities [49].

Participation of individuals with autism in regular physical activity practices can significantly contribute to the development of motor coordination, body awareness, social interaction, daily independence, and cognitive abilities. Physical activities include jogging, mini- 
trampoline, water activities, horse riding, skating, as well as aerobic activities [50]. After the Covid-19 outbreak, performing outdoor physical activities has become almost impossible all around the world. During the pandemic, performing simple, safe, and easy exercises is very important to maintain a healthy fitness level. Balance exercises performed at home should be carried out on a soft surface like pillows and cushions; they should gradually progress to more difficult tasks: double stance, eyes open, and closed, and then single stance, eyes open, and closed. In order to minimize the risk of falling during the exercise, balance training should be closely monitored at first, training should start with less challenging postures, and the training should progress gradually [51]. Simple household items such as filled water bottles, canned foods, or food packages can be useful for weight exercises [32, 52]. Exercises can be performed in quarantine conditions since they do not require any specific tools. In terms of practicable exercises at home, many modern audiovisual tools, such as social media, e-health, home education applications, and physical activity videos can be used through the Internet $[32,52]$. It is important to emphasize that there is no ideal exercise plan for individuals with autism and the same activity can produce different results for each participant, so it is important to evaluate individual characteristics and intended goals.

It is possible to say that regular physical activity for children diagnosed with autism spectrum disorder not only reduces stereotyped behaviors, but also positively affects their psychomotor development, motor coordination, agility, speed, and strength [50]. Handling young children with special needs, such as the autism spectrum condition, can be difficult for families and caregivers. Usually, these children have interventions at home with private therapists or in private hospitals and institutes for a few hours a week. However, at present, both families and autism spectrum children are not physically supported by their therapists and cannot participate in external interventions due to Covid-19 prevention measures [53].

\section{CONCLUSION}

There is a big difference between choosing involuntary self-isolation, choosing selfisolation out of necessity, or being forced into it. Many autistic and otherwise disabled individuals live isolated lives for self-protection rather than preference. Exclusion, bullying, harassment and abuse, inaccessible physical and social environments, and the lack of appropriate services and support mean that self-isolation is the only option for many. During the pandemic, a huge community in the world faces the conditions in which many autistic persons or those with different disabilities find themselves every day. It is hoped that the isolation experiences of the non-disabled individuals during the epidemic will encourage empathy and the formation of more collaborative communities in working with the disabled when the epidemic is over [23].

Disabled people represent a significant portion of world population. For this reason, the disability perspective should not be ignored while making legislation, policies, and practices. Being a society that neglects the needs of disabled people should be avoided [3]. Access to information and communication technologies, which are tools to reduce the negative impact of social isolation and physical distance on the lives of people with disabilities and their families, needs to be financially strengthened. It is necessary to provide technologies for persons with disabilities and their families and provide training regarding their use. Psychosocial support should be provided to persons with disabilities and their families and support networks for them should be strengthened [24]. For persons with disabilities, flexibility in restricting movement in public spaces should be adopted, and different working hours should be established for the disabled and other vulnerable groups.

Disability is part of human diversity, like race and gender. Persons with disabilities represent a significant part of the population in all countries. We should not ignore the disability 
perspective while making our legislation, policies, and practices [3]. It is hoped that the countries affected by the Covid-19 pandemic will take into account the needs of persons with disabilities in emergency preparedness and response plans. Providing psychosocial support to people with disabilities and their families and strengthening support networks for persons with disabilities and controlling the virus as quickly as possible are public health priorities; however, guidelines need to be prepared and the public need to be informed about what they can or should do to maintain their daily exercise or physical activity routines.

\section{REFERENCES}

[1] WHO (World Health Organization). Novel Coronavirus-China. [https://www.who.int/csr/don/12-january-2020-novel coronavirus-china/en/] [access: 18 May 2020].

[2] WHO (World Health Organization). Coronavirus Disease (COVID-19) Dashboard. [https://covid19.who.int/] [Accessed: 18 May 2020].

[3] Qi F, Hu L. Including people with disability in the COVID-19 outbreak emergency preparedness and response in China. Disabil Soc. 2020;0(0):1-6. https://doi.org/10.1080/09687599.2020.1752622

[4] Cascella M, Rajnik M, Cuomo A, Dulebohn SC, Di Napoli R. Features, evaluation and treatment coronavirus (COVID-19). In Statpearls [internet] 2020, StatPearls Publishing.

[5] Jalali M, Shahabi S, Bagheri Lankarani K, Kamali M, Mojgani P. COVID-19 and disabled people: Perspectives from Iran. Disabil Soc. 2020;0(0):1-4. https://doi.org/10.1080/09687599.2020.175416511.

[6] 6. Yuen KS, Ye ZW, Fung SY, Chan CP, Jin DY. SARS-CoV-2 and COVID-19: The most important research questions. Cell and Bioscience. 2020;10(1):1-5. https://doi.org/10.1186/s13578-020-00404-4

[7] WHO (World Health Organization). Disability considerations during the COVID-19 outbreak COVID-19. [https:// www.who.int/publications-detail/disability-considerations-during-the-covid-19-outbreak] [Accessed: 18 May 2020 ].

[8] Thelwall M, Levitt JM. Retweeting Covid-19 disability issues: Risks, support and outrage. El Profesional de La Información. 2020;29(2):1-6. https://doi.org/10.3145/epi.2020.mar.16

[9] Turkish Statistical Institution. 2002. Engellilik Oranı [The Proportion of Disability] [http://www.tuik.gov.tr/VeriBilgi. do?alt_id=1017] [Accessed: 18 May 2020].

[10] WHO (World Health Organization). Summary World Report On Disability. In World Health. 2011. https://doi.org/10.1136/ ip.2007.018143

[11] Ng K. Adapted Physical Activity through COVID-19. EUJAPA. 2020;13(1):1. https://doi.org/10.5507/euj.2020.003

[12] Frost S. Deadly discrimination: The forgotten impact of Covid-19 on people with disabilities. Forbes. 2020. [Available at https://www.forbes.com/sites/sfrost/2020/07/06/deadly-discrimination/?sh=1ccbdddf2b93]. [Accessed: 13 Oct 2021].

[13] Pineda VS, Corburn J. Disability, urban health equity, and the coronavirus pandemic: Promoting cities for all. J Urban Health. 2020;97:336-341 https://doi.org/10.1007/s11524-020-00437-7

[14] Nicolaidis C, Raymaker D, Mcdonald K, et al. Comparison of healthcare experiences in autistic and non-autistic adults: A cross-sectional online survey facilitated by an academic-community partnership. J Gen Intern Med. 2013;28(6):761769. https://doi.org/10.1007/s11606-012-2262-7

[15] Sabatello M, Burke TB, McDonald KE, Appelbaum PS. Disability, Ethics, and Health Care in the COVID-19 Pandemic. Am J Publ Health. 2020;(0):e1-e5.

[16] Courtenay K, Perera B. COVID-19 and people with intellectual disability: impacts of a pandemic. Irish J Psychol Med. 2020;37(3):231-236. https://doi.org/10.1017/ipm.2020.45

[17] Ee D, Hwang YI, Reppermund S, et al. Loneliness in adults on the autism spectrum. Autism Adult. 2019;1(3):182-193. https://doi.org/10.1089/aut.2018.0038

[18] Vengoechea J, Garcia AG. Intellectual and developmental disabilities. Handbook of Clinical Adult Genetics and Genomics. 2020; 249-259. https://doi.org/10.1016/b978-0-12-817344-2.00016-2

[19] Tseng TG, Wu HL, Ku HC, Tai CJ. The impact of the Covid-19 pandemic on disabled and hospice home care patients. The Journals of Gerontology. Series A, Biol Sci Med Sci. 2020;XX(Xx):1-2. https://doi.org/10.1093/gerona/glaa081

[20] Mörchen M, Kapoor H, Varughese S. Disability and COVID 19. Commun Eye Health J. 2020;33(109):6-7.

[21] Baart J, Taaka F. Barriers to healthcare services for people with disabilities in developing countries: A literature review. Disability, CBR and Inclusive Development. 2017;26-40. https://doi.org/10.5463/DCID.v29i4.656

[22] Fallon K. Exercise in the time of COVID-19. Austr J Gen Practice. 2020;49 Suppl 13. https://doi.org/10.31128/ajgp-covid-13

[23] Den Houting J. Stepping out of isolation: Autistic people and COVID-19. Autism Adult. 2020;2(2):1-3. https://doi. org/10.1089/aut.2020.29012.jdh

[24] ECLAC (Economic Commission for Latin America and the Caribbean) (2020) Persons with disabilities and coronavirus disease (COVID-19) in Latin America and the Caribbean: status and guidelines.

[25] Yarimkaya E, Esenturk OK. Promoting physical activity for children with autism spectrum disorders during Coronavirus outbreak: Benefits, strategies, and examples. Int J Develop Disabil. 2020;0(0):1-6. https://doi.org/10.1080/204738 69.2020 .1756115

[26] Rydzewska E, Hughes-Mccormack LA, Gillberg C, et al. Prevalence of sensory impairments, physical and intellectual disabilities, and mental health in children and young people with self/proxy-reported autism: Observational study of a whole country population. Autism. 2019;23(5):1201-1209. https://doi.org/10.1177/1362361318791279

[27] Neumeyer AM, Anixt J, Chan J, et al. Identifying associations among co-occurring medical conditions in children with autism spectrum disorders. Acad Pediatr. 2019;19(3):300-306. https://doi.org/10.1016/j.acap.2018.06.014 
[28] Raymaker DM, Mcdonald KE, Ashkenazy E, et al. Barriers to healthcare: Instrument development and comparison between autistic adults and adults with and without other disabilities. Autism. 2017;21(8):972-984. https://doi. org/10.1177/1362361316661261

[29] Leigh-Hunt N, Bagguley D, Bash K, et al. An overview of systematic reviews on the public health consequences of social isolation and loneliness. Publ Health. 2017;152:157-171. https://doi.org/10.1016/j.puhe.2017.07.035

[30] Armitage R, Nellums LB. The COVID-19 response must be disability inclusive. Lancet. Publ Health. 2020;5(5):e257. https://doi.org/10.1016/S2468-2667(20)30076-1

[31] Chen P, Mao L, Nassis GP, Harmer P, Ainsworth BE, Li F. Wuhan coronavirus (2019-nCoV): The need to maintain regular physical activity while taking precautions. J Sport Health Sci. 2020;9(2):103-104. https://doi.org/10.1016/j. jshs.2020.02.001

[32] Chen P, Mao L, Nassis GP, Harmer P, Ainsworth B, Li F. Returning Chinese school-aged children and adolescents to physical activity in the wake of COVID-19: Actions and precautions. J Sport Health Sci. 2020;9(4):322-324. https:// doi.org/10.1016/j.jshs.2020.04.003

[33] Ntoumanis N, Thøgersen-Ntoumani C, Quested E, Hancox J. The effects of training group exercise class instructors to adopt a motivationally adaptive communication style. Scand J Med Sci Sport. 2017;27(9):1026-1034. https://doi. org/10.1111/sms.12713

[34] Falvey JR, Krafft C, Kornetti D. The essential role of home-and community-based physical therapists during the COVID-19 pandemic. Phys Ther. 2020;100(7):1058-1061.

[35] Schiariti V. The human rights of children with disabilities during health emergencies: The challenge of COVID-19. Develop Med Child Neurol. 2020;66(6):661-661. https://doi.org/10.1111/dmcn.14526

[36] Ghinai I, Mcpherson TD, Hunter JC, et al. First known person-to-person transmission of severe acute respiratory syndrome coronavirus 2 (SARS-CoV-2) in the USA. Lancet. 2020;395(10230):1137-1144. https://doi.org/10.1016/ S0140-6736(20)30607-3

[37] Thevarajan I, Nguyen THO, Koutsakos M, et al. Breadth of concomitant immune responses prior to patient recovery: A case report of non-severe COVID-19. Nature Med. 2020;26(4):453-455. https://doi.org/10.1038/s41591-020-0819-2

[38] Soy M, Keser G, Atagündüz P, Tabak F, Atagündüz I, Kayhan S. Cytokine storm in COVID-19: Pathogenesis and overview of anti-inflammatory agents used in treatment. Clini Rheumatol. 2020;39:085-2094. https://doi.org/10.1007/ s10067-020-05190-5

[39] Zhang C, Wu Z, Li JW, Zhao H, Wang GQ. The cytokine release syndrome (CRS) of severe COVID-19 and interleukin-6 receptor (IL-6R) antagonist tocilizumab may be the key to reduce the mortality. Int J Antimicr Agents. 2020;55(105954):1-6. https://doi.org/10.1016/j.ijantimicag.2020.105954

[40] Zhou P, Yang XL, Wang XG, et al. A pneumonia outbreak associated with a new coronavirus of probable bat origin Nature. 2020;579(7798):270-273. https://doi.org/10.1038/s41586-020-2012-7

[41] Nieman DC, Wentz LM. The compelling link between physical activity and the body's defense system. J Sport Health Sci. 2019;8(3):201-217. https://doi.org/10.1016/j.jshs.2018.09.009

[42] Fisher D, Heymann D. Q\&A: The novel coronavirus outbreak causing COVID-19. BMC Med. 2020;18(1):1-3. https:// doi.org/10.1186/s12916-020-01533-w

[43] Martin SA, Pence BD, Woods JA. Exercise and respiratory tract viral infections. Exerc Sport Sci Rev. 2019;37(4):157164. https://doi.org/10.1097/JES.0b013e3181b7b57b

[44] Bermon S, Castell LM, Calder PC, et al. Consensus statement immunonutrition and exercise. Exerc Immunol Rev. 2017;23:8-50.

[45] Laddu DR, Lavie CJ, Phillips SA, Arena R. Physical activity for immunity protection: Inoculating populations with healthy living medicine in preparation for the next pandemic. Progress Cardiov Dis. 2020;4-6. https://doi.org/10.1016/j. pcad.2020.04.006

[46] Wong CM, Lai HK, Ou CQ, et al. Is exercise protective against influenza-associated mortality? PLoS One. 2008;3(5):1-7. https://doi.org/10.1371/journal.pone.0002108

[47] Woods JA, Keylock KT, Lowder T, et al. Cardiovascular exercise training extends influenza vaccine seroprotection in sedentary older adults: the immune function intervention trial. J Am Geriatr Soc. 2009;57(12):2183-91. https://doi. org/10.1111/j.1532-5415.2009.02563.x

[48] Smith B, Sparkes A. Disability, sport and physical activity. A Critical Review. In N. Watson, A. Roulstone, \& C. Thomas (Eds.), Routledge Handbook of Disability Studies. 2012;336-347.

[49] Sport England. Active Lives Adult Survey 16/17 Report 2017;October,1-18. https://www.sportengland.org/media/12458/ active-lives-adult-may-16-17-report.pdf

[50] Aniszewski E, Almeida H, Alvernaz A. Benefits of physical activity for the development of autistic children. Int Phys Med Rehab J. 2020;5(2):79-80.

[51] Arslan E, Ercan, S. Significance of exercise during COVID-19 pandemic and social distancing. Turk J Sports Med. 2020;55(2):188-91. https://doi.org/10.5152/tjsm.2020.190

[52] Guo Y, Qiu P, Liu T, Tai JQ. An overview of its history, health benefits, and cultural value. J Sport Health Sci. 2014;3(1):3-8.

[53] Narzisi A. Handle the autism spectrum condition during Coronavirus (COVID-19) stay at home period: Ten tips for helping parents and caregivers of young children. Brain Sci. 2020;10(207):1-4. 